\title{
Sounds of Prejudice: Background Music During Victim Impact Statements
}

\section{INTRODUCTION}

Music has the ability to bring up past memories, to transport us to another place and time. Each specific song has its own unique connotation: "Pomp and Circumstance" with graduation, "Amazing Grace" with funerals, "Here Comes the Bride" with weddings, ${ }^{3}$ and "Stayin' Alive" with John Travolta and disco. ${ }^{4}$ Even music we have never heard before has an effect on us and can change the mood of our current surroundings. It tells us when to feel anxious during scary movies; in happier ones, it lets us know when the guy is about to get the girl.

Music's powerful effect on emotion makes it a dangerous addition to the supposedly logic-and-reason-based setting of a courtroom. This added emotion makes it even more difficult for jurors to set aside their feelings and make rational decisions. Yet, numerous courts have somehow allowed music to be played at a time when emotional decisions can be very dangerous to a defendant: during his sentencing.

Imagine the jurors trying to determine a sentence, after already convicting a defendant for murder, listening to the grief-stricken family of the victim describe how the crime has changed their lives. And at the conclusion of the already highly emotional testimony, the prosecutor presents a picture montage of the victim's entire life, while Celine Dion's "My Heart Will Go On" plays in the background. ${ }^{5}$ The court then

Erica A. Schroeder. J.D. candidate 2010, University of Kansas School of Law; B.S. 2006, University of South Dakota. Special thank you to Professor Jean Gilles Phillips and to Ethan ZipfSigler for their valuable comments and suggestions on earlier drafts and to the Kansas Law Review Staff and Board for all their hard work throughout the editing process.

1. Edward Elgar, Pomp and Circumstance March No. 1, on Marches Greatest Hits (Sony 1994).

2. John Newton, Amazing Grace, on OlNEY HyMns (Newton 1779).

3. Richard WAgner, Bridal Chorus, on THE BeSt OF WAGNER (RCA 1991).

4. Bee Gees, Stayin' Alive, on SATURday Night Fever (RSO 1977).

5. Celine Dion, My Heart Will Go On, on Titanic: Music from the Motion Picture (Epic 1997). 
instructs the jurors to weigh the facts and make an informed and rational decision, a difficult request in any sentencing, but made even more impossible after the music unnecessarily stirred up additional emotion.

Several courts have allowed prosecutors to present videos with background music exactly as described in the above scenario. At a sentencing hearing, prosecutors may present evidence in the form of victim impact statements (VIS) to inform the jury of the harm caused by the defendant. Such statements play an important part in the judicial process, but there needs to be a limit to what VIS can entail.

The current trend of advancing technology has made the use of electronic media during VIS a widespread phenomenon. In addition to live testimony from family, more prosecutors today are using technology, such as PowerPoint presentations or videos, to visually present the lives of deceased victims. Many of these presentations are set to emotional background music - an irrelevant and highly prejudicial addition to otherwise admissible VIS. Allowing such music during VIS causes prejudicial emotional decisions resulting in a fundamentally unfair sentencing, and courts should no longer allow music during VIS.

Those courts deciding on the admissibility of musical VIS have not uniformly agreed upon its admission, and the current standard of admissibility set out by the Supreme Court is not consistently applied. A closer look at the scientific evidence demonstrating music's prejudicial impact on emotion and decision-making shows that allowing music during VIS creates a high risk that jurors will make decisions based on emotion instead of reason. This risk cannot be tolerated, especially when there is no way to determine whether inappropriate factors influenced the sentence.

This comment will discuss the prejudicial impact of allowing emotional music during VIS, focusing primarily on the admission of such music during capital sentencing by juries. Part II explains music's proven effect on emotion and provides an overview of the background of VIS in general, including the case history and current standards for allowing VIS. Part III analyzes the inconsistency of courts' attempts to apply the current standard of admissibility for VIS involving music. Part III also includes a discussion of emotion's prejudicial effect on decisionmaking and provides an overview of why music should be inadmissible during VIS. Part IV concludes the discussion with a suggestion that courts universally ban music during VIS. 


\section{BACKGROUND}

To understand the danger of allowing music during VIS, it is necessary to understand music's proven ability to influence emotion. The history and function of VIS are also relevant to why courts have allowed music at all.

\section{A. Music's Prejudicial Effect on Emotion}

Music has the power to produce varying physical responses of which we are aware, such as tears and goose bumps; it may also cause lessnoticeable physical reactions including decreased blood pressure, reduced stress, hormone suppression, and muscle relaxation. ${ }^{6}$ But one of music's best-known results is its effect on emotion. It is common knowledge that music adds to visual effects - a movie just would not be the same with dialogue alone. But what is it about music that causes such an emotional response?

There are two widespread theories regarding music's effect on emotion: (1) the expression theory, which assumes music itself expresses emotion that is simply recognized by the listener; and (2) the arousal theory, which speculates that music brings out or even generates emotion in the listener. ${ }^{7}$

The expression theory argues that how a listener experiences music is somewhat similar to how one interprets body language, facial expressions, or gestures. ${ }^{8}$ Throughout our lives, we become "experts" in observing and can readily match non-verbal cues with previously formed subconscious beliefs. ${ }^{9}$ Thus, depending on what non-verbal cues a speaker is sending, a pleasant message may be received as angry or unkind. Similarly, sad or sorrowful music can bring an unhappy mood into an otherwise enjoyable experience. ${ }^{10}$

The arousal theory, on the other hand, maintains that music itself has the power to elicit emotion in the listener. Klaus Scherer and Marcel Zentner propose that emotions can be created by musical stimuli in three

6. See Klaus R. Scherer \& Marcel R. Zentner, Emotional Effects of Music: Production Rules, in Music AND EMOTION: THEORY AND RESEARCH 361, 374 (P.N. Juslin \& J.A. Sloboda eds., 2001).

7. Iben Have, Background Music and Background Feelings: Background Music in AudioVisual Media, 6 J. Music \& MeANING § 5, 5.4 (2008).

8. Id.

9. See id. (stating that we are "experts in observing and creating meaning from other people's gestures").

10. See id. (stating that background music that is gentle can alter one's experience of a visually and verbally unsympathetic person). 
ways: through appraisal, memory, or empathy. ${ }^{11}$ When emotions are created through appraisal of music, our bodies automatically process and evaluate the music against personal criteria to decide whether it is cheerful or sorrowful. ${ }^{12}$ Additionally, memories can bring back past emotions when an individual has a reaction to a specific song or sound. ${ }^{13}$

The third way emotions may be created through music is by empathy, or through the phenomenon of feeling emotions based on observing. ${ }^{14}$ Listening to expressive music is similar to observing others' emotions and, as such, can lead to the generation of a similar emotion in the observer. ${ }^{15}$ This possibility that music can create empathy is especially concerning when music is introduced into the already highly emotional setting of VIS. Any information jurors receive from VIS should be based on the words of the victim's family. Not only is it unfair to add accompanying mournful music that will generate further empathy, but it creates a grave danger of emotional decisions by the jury.

Of course, the specific emotional reaction will depend upon the type of music. Studies have shown that music can be reliably described using basic emotional expressions such as happy, sad, or fearful. ${ }^{16}$ Although the music's performance may be a factor, the listener's interpretation may be influenced even more by culture, personality, experience, musical expertise, specific memories, or mood. ${ }^{17}$ Additionally, contextual aspects of the location and event where the music is played affect the listener, not only for acoustic purposes, but as a result of the surrounding atmosphere-which could be anything from a funeral to a holiday party. ${ }^{18}$ In short, Scherer and Zentner determined that emotions actually experienced by a listener can be determined by a formula consisting of all the aforementioned factors: the melody itself, the manner of performance, the personality and experiences of the listener, and the location or event where the music is heard. ${ }^{19}$ Because not every

11. Scherer \& Zentner, supra note 6, at 366-71.

12. See id. at 366 (discussing the process of evaluating an event).

13. Id. at 369 .

14. Id.

15. Id. at $369-71$.

16. Carol L. Krumhansl, Music: A Link Between Cognition and Emotion, 11 Current DIRECTIONS IN PSYCHOL. SCI. 45, 46 (2002).

17. Scherer \& Zentner, supra note 6 , at 364 .

18. Id. at $364-65$.

19. See id. at 365 . The formula in more scientific detail is written as: "Experienced emotion $=$ Structural features [melody, tempo, rhythm, and harmony] x Performance features [performer identity, ability, and state] x Listener features [culture, personality, expertise, mood, and memories] x Contextual features [location and event].” Id. 
condition will be present at all times, the different factors will carry different weight depending on the individual listener. ${ }^{20}$

Not only have studies identified factors of music that affect emotion, more importantly, some have actually shown how music affects a listener's emotions. Although opponents argue and have shown that emotions can arise through an individual's personal connection with specific tones, it is apparent that music must actually produce emotionotherwise emotions from the same music would vary from person to person depending on his or her past experiences. ${ }^{21}$ This, however, is not the case, as different people with different experiences have similar emotions upon hearing the same song. In fact, studies using brainimaging techniques have proven that music causes an involuntary reaction in us all, even in those incapable of producing memories. ${ }^{22}$

Several studies have focused on background music's influential effect on a listener. For example, a study based on five- and six-yearolds by Naomi Ziv and Maya Goshen in 2006 found that background music influenced interpretation of a neutral story as either happy or sad. ${ }^{23}$ Children hearing happy background music (in a major key) recalled specific neutral events from the story as happy and regarded the story as happy in general. ${ }^{24}$ Although the results were somewhat less noticeable, children listening to sad background music (in a minor key) interpreted the same events from the story as sad. ${ }^{25}$ Based on these results, it is conceivable that jurors who view pictures in a montage or listen to a family member speak while listening to sad or sentimental music will interpret those pictures differently than jurors who hear no music at all. And as the next study will show, the emotional impact of such music is magnified when the pictures or words themselves have a sad connotation.

Because music coupled with neutral experiences can create emotions based on the feelings given by the music, it is not surprising that music heard during experiences that are by themselves either positive or negative can strengthen those feelings even more. Music attached to an emotional narrative can shape feelings based on the type of narrative, the

20. Id

21. Krumhansl, supra note 16 , at 45.

22. See id. at 49 (discussing results of studies using infants and individuals suffering from brain damage).

23. Naomi Ziv \& Maya Goshen, The Effect of 'Sad' and 'Happy' Background Music on the Interpretation of a Story in 5 to 6-Year-Old Children, 23 BRIT. J. MUSIC. EDUC. 303, 311 (2006).

24. $I d$.

25. Id. 
circumstances surrounding the communication, the listener's ability to empathize, and any other messages in the music from the sender. ${ }^{26}$ Thus, when sad music is played during a mournful narrative in the somber atmosphere of a sentencing hearing, the jury's initial emotions will be greatly and unnecessarily intensified.

When music is coupled with visual stimuli, such as pictures, the influence on emotion is even more prominent. Everyday experiences with music in films and television has taught us to quickly extract meaning from accompanying music - it is easy to tell when to be happy and when to be sad. This interpretation happens subconsciously, similar to how one recognizes body language. ${ }^{27}$ One study using brain scan technology showed that emotional pictures alone can evoke emotion, but combining emotional pictures with emotional music heightens the experience, "automatically evok[ing] (strong) emotional feelings and experiences." 28 Because of this automatic response, it is impossible to ask jurors simply to ignore prejudicial background music. The only option is to ban it from VIS altogether.

These studies have clearly shown that music can both cause and strengthen emotion in its listeners. Under either theory, the result is clear: music has an impact on emotion. This emotion, in turn, has a highly prejudicial effect on a jury's supposedly neutral decision. To fully appreciate this impact, it is important to understand the background and current state of law regarding VIS admission.

\section{B. Victim Impact Statements in General}

VIS are defined as "statement[s] read into the record during sentencing to inform the judge or jury of the financial, physical, and psychological impact of the crime on the victim and the victim's family." ${ }^{29}$ VIS may vary from one jurisdiction to another, but a typical statement may accomplish one or more tasks: (1) identifying the victim, (2) itemizing economic loss, (3) identifying the seriousness and permanence of physical injury, (4) describing changes in the victim's

26. Have, supra note 7 , at $\S 5.5$. Of course, the expression and arousal theories still apply and there may be differences between what a listener thinks the speaker is feeling and what the listener himself is feeling. This difference will depend on the listener's attention and empathetic abilities. See id. A listener's feelings will not necessarily match the subjective feelings of the narrative: one may feel pity when hearing of another's sorrow.

27. Id.

28. Thomas Baumgartner et al., The Emotional Power of Music: How Music Enhances the Feeling of Affective Pictures, 1075 BRAIN RES. 151, 160 (2006).

29. BLACK'S LAW DiCTIONARY 1598 (8th ed. 2004). 
personal welfare or family relationships, (5) identifying requests for psychological services initiated by the victim or his family, or (6) conveying other information related to the impact of the offense upon the victim or the family as required by the court. ${ }^{30}$

One problem with VIS is the broad discretion given to trial courts as to the type and amount of information admissible during VIS. This discretion naturally results in inconsistent decisions regarding its admission, especially when it comes to music. Although VIS are not regulated specifically by the Federal Rules of Evidence, they are governed by a strikingly similar test. ${ }^{31}$ The Federal Rules of Evidence Rule 403 declares that "evidence may be excluded if its probative value is substantially outweighed by the danger of unfair prejudice, confusion of the issues, or misleading the jury, or by considerations of undue delay, waste of time, or needless presentation of cumulative evidence." ${ }^{32}$ In both state and federal courts, VIS must be excluded for similar reasons. ${ }^{33}$ Evidence admitted during the sentencing phase of criminal trials should pass this test-although again, this is subject to much judicial discretion. Courts' views of the prejudicial impact of VIS have changed throughout history, and although courts once completely banned the use of VIS in capital cases for being too prejudicial, recent courts have taken the opposite approach and rarely find information provided during VIS to be unduly prejudicial. Given the Supreme Court's past hesitation in admitting VIS in any capital sentencing, ${ }^{34}$ this trend is unsettling, especially when it comes to the prejudicial use of music during VIS. But even when music is not involved, there is still disagreement over VIS and their role in a defendant's sentencing.

\section{Arguments for and Against the General Use of Victim Impact Statements}

The battle for victims' rights outside the courtroom began in the 1940s and reached its peak during the 1970s. ${ }^{35}$ The focus on such rights was driven by multiple factors: public dissatisfaction with the criminal justice system's treatment of victims, prosecutorial hopes of help from

30. Booth v. Maryland, 482 U.S. 496, 498-99 (1987), overruled by Payne v. Tennessee, 501 U.S. 808 (1991).

31. See infra Part II.D (discussing the application of the Payne Court's test).

32. FED. R. EVID. 403.

33. See infra Part II.B (discussing the allowance of VIS under state and federal rules).

34. See infra Part II.C (discussing the history of case law involving VIS).

35. See Bryan Myers \& Edith Greene, The Prejudicial Nature of Victim Impact Statements: Implications for Capital Sentencing Policy, 10 PSYCHOL. PUB. POL'Y \& L. 492, 493 (2004). 
victims in securing convictions, and politicians' desires to appear tough on criminals and sympathetic toward victims. ${ }^{36}$ Probably the largest change in victims' rights is the inclusion of VIS during sentencing.

Even with past trends supporting victims' rights, the debate over VIS continues today. Advocates of VIS argue that allowing statements provides numerous advantages: victims and families may receive psychological benefits, the opportunity for victims to share personal qualities and character traits results in improved attitudes toward the criminal process in general, and its use results in more consistent and proportional sentences. ${ }^{37}$

The Supreme Court has recognized some alternative arguments for allowing VIS. First, it reasoned that some evidence about the victim would no doubt be admitted during the guilt phase of the trial. ${ }^{38}$ Second, it would be impossible for a sentencing jury to be completely free of evidence of the victim without having separate juries for the guilt and sentencing phases and introducing VIS during sentencing did nothing more than add to what the jury already knew. ${ }^{39}$ Finally, the Court found that not allowing the State to submit evidence during the sentencing phase placed an unfair burden on the State:

[T]he State has a legitimate interest in counteracting the mitigating evidence which the defendant is entitled to put in, by reminding the sentencer that just as the murderer should be considered an individual, so too the victim is an individual whose death represents a unique loss to society and in particular to his family. ${ }^{40}$

Another argument of which VIS supporters may be less aware is that victims sometimes send a message of forgiveness or a desire for leniency to the jurors. For example, during the sentencing of James Bernard Campbell's first two trials for the murder of Reverend Billy Bosler, the victim's daughter, who had also been attacked by Campbell, gave emotional testimony about the attack and her life after her father's death. ${ }^{41}$ Both times the jury sentenced Campbell to death, although both

37. Id.

38. Payne v. Tennessee, 501 U.S. 808, 839-41 (1991) (Souter, J., concurring).

39. Id.

40. Id. at 825 (majority opinion) (alteration in original) (quoting Booth v. Maryland, 482 U.S. 496, 517 (1987) (White, J., dissenting)).

41. Beth E. Sullivan, Note, Harnessing Payne: Controlling the Admission of Victim Impact Statements to Safeguard Capital Sentencing Hearings from Passion and Prejudice, 25 FoRDHAM URB. L.J. 601, 601-02 (1998). 
sentences were later remanded for resentencing for other reasons. ${ }^{42}$ The third time she took the stand, Bosler's daughter changed her position and opposed Campbell's death sentence to uphold the beliefs of her father, who opposed the death penalty. ${ }^{43}$ This time the jury came back in three hours with a sentence of life imprisonment. ${ }^{44}$

Critics of VIS cite numerous drawbacks of allowing such evidence into the sentencing phase. One major concern regarding VIS is the prejudicial and inflammatory nature of the testimony. ${ }^{45}$ Additionally, the majority of victims do not participate in the sentencing phase, as only nine percent make oral statements to the decision-maker. ${ }^{46}$ VIS are inconsistent with the notion that crimes are violations against the state rather than an individual person, as it is the state and not the victim's family who is bringing suit. ${ }^{47}$ Those who violate laws should be convicted because public interest requires it, not simply according to the desires of the individual victim - whether forgiving or vengeful. ${ }^{48}$

As a result, VIS introduce inconsistencies in sentencing because emotional testimony and victim qualities, rather than the defendant's actions, become the focus of sentencing. ${ }^{49}$ Fairness suggests that "like cases ought to be treated alike, ${ }^{, 50}$ and Congress appears to have had this goal in mind when enacting the Federal Uniform Sentencing Guidelines. ${ }^{51}$ And yet, sentences differ for similar crimes, suggesting that VIS play an important role. Numerous studies using mock jurors have shown the influence VIS have on sentencing judgments-juries hearing VIS typically give significantly harsher sentence recommendations and are more likely to impose the death penalty than those who do not hear VIS. ${ }^{52}$

42. See Campbell v. State, 679 So. 2d 720, 729 (Fla. 1996) (remanding for improper comments made by prosecutor to the jury); Campbell v. State, 571 So. 2d 415, 420 (Fla. 1990) (remanding to include mitigating factors of defendant's impaired capacity).

43. Sullivan, supra note 41 , at 602 .

44. Id. at 603 .

45. Myers \& Greene, supra note 35, at 493-94.

46. Id. at 493 .

47. Id. 503.

48. Andrew Ashworth, Victim Impact Statements and Sentencing, 1993 CRIM. L. REV. 498,

49. Myers \& Greene, supra note 35, at 493.

50. Stephen J. Schulhofer, Harm and Punishment: A Critique of Emphasis on the Results of Conduct in the Criminal Law, 122 U. PA. L. REV. 1497, 1601 (1974).

51. Sentencing Reform Act of 1984, 18 U.S.C. $\S \S 3551-3581$ (2006).

52. See, e.g., Bryan Myers \& Jack Arbuthnot, The Effects of Victim Impact Evidence on the Verdicts and Sentencing Judgments of Mock Jurors, 29 J. OFFENDER REHAB. 95, 197-98 (1999); see also James Luginbuhl \& Michael Burkhead, Victim Impact Evidence in a Capital Trial: Encouraging Votes for Death, 20 AM. J. CRIM. JUST. 1 (1995). 
Finally, it is difficult for the defendant to introduce rebuttal testimony concerning the victim's character. Although some courts afford a defendant the right to cross-examine victim character evidence, this right is not universally recognized. ${ }^{53}$ And even if a defendant has such a right, it may not be in his best interest to exercise it, as a vigorous cross-examination of impact witnesses drawing attention to the victim's flaws is not the most tactful approach. The Supreme Court has recognized this difficulty, although it did not find the difficulty so compelling as to ban VIS altogether. ${ }^{54}$

\section{Current State and Federal Allowance in Capital Trials}

Although no rules require the admission of VIS, the majority of jurisdictions currently authorize their general use, many providing no reasoning other than citing Payne v. Tennessee, the Supreme Court's opinion allowing their admission. ${ }^{55}$ The limits and guidelines for admitting VIS — if any are provided at all—vary greatly by jurisdiction. All fifty states allow some sort of VIS in non-capital sentencing. ${ }^{56}$

53. Compare Proffitt v. Wainwright, 685 F.2d 1227, 1255 (11th Cir. 1982) (finding a right to cross-examine exists during capital sentencing), with Bassette v. Thompson, 915 F.2d 932, 939 (4th Cir. 1990) (finding no right to cross-examine during capital sentencing).

54. See Payne v. Tennessee, 501 U.S. 808, 823 (1991) (“[T]he mere fact that for tactical reasons it might not be prudent for the defense to rebut victim impact evidence makes the case no different than others in which a party is faced with this sort of dilemma.").

55. See John H. Blume, Ten Years of Payne: Victim Impact Evidence in Capital Cases, 88 CORNELL L. REV. 257, 267-68 (2003) (stating that thirty-three of the thirty-eight states that have the death penalty allow VIS and that most states have made this decision with little or no reasoned analysis other than a citation to Payne).

56. The following state statutes specifically provide for victim impact evidence from the victim's family in some form or another: ALASKA STAT. ANN. § 12.55.022 (West 2007); ARIZ. REV. Stat. ANN. § 13-702 (2001); ARK. Code ANN. §§ 5-65-102, -109 (West 2008); CAL. Penal Code § 1191.1 (West 2000); Colo. Rev. Stat. ANN. §§ 24-4.1-302, -302.5 (West 2008); ConN. GEN. STAT. ANN. § 54-220 (West 2009); Del. Code ANN. tit. 11, § 4331 (West 2006); D.C. CoDE § 23-103 (2001); FLA. STAT. ANN. § 921.143 (West 2001); Ga. CODE ANN. § 17-10-1.2 (West 2003); IDAHO Code ANN. § 19-5306(1), (3) (West 2006); 725 Ill. Comp. Stat. ANN. 120/6 (West 2008); IND.

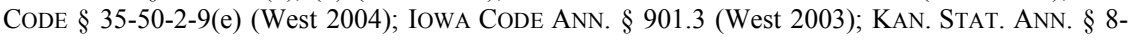
1019 (2008); Ky. Rev. Stat. ANN. \$§ 421.500, .520 (West 2006); LA. Code Crim. Proc. ANN. art. 875(B) (2008); ME. Rev. STAT. AnN. tit. 15, § 6101, tit. 17-A § 1257 (2006); MD. Code ANN., Crim. Proc. § 11-403 (West 2002); MASS. Gen. LaWs ANN. ch. 258B, § 3(p) (West 2004); Mich. COMP. LAWS ANN. $\S \S 780.752, .791$ (West 2007); MinN. STAT. ANN. §§ 611A.01, .037 (West 2009); Miss. Code ANN. § 99-19-151 to -161 (West 2006); Mo. ReV. STAT. § 217.762 (1993); MonT. Code ANN. § 46-18-112 (2009); NeB. REV. StAT. ANN. § 29-2521 (West 2009); N.H. ReV. STAT. ANN. § 651:4-a (2007); N.J. STAT. ANN. § 2C:44-6 (West 2005); N.M. STAT. ANN. §§ 31-263, -4 (West 2003); N.Y. Crim. Proc. § 390.30(3)(b) (McKinney 2005); N.C. Gen. Stat. ANN. § 15A-825 (West 2009); N.D. Cent. CODE ANN. \$§ 12.1-34-01, -02(14) (West 2008); OHIO ReV. CODE ANN. §§ 2947.051, 2929.12 (West 2006); OKLA. STAT. ANN. tit. 22, §§ 982, 984 (West 2003); Or. Rev. Stat. ANN. §§ 137.530(3), 144.790(3) (West 2003); 42 PA. CONS. Stat. AnN. § 9738 (West 2007); R.I. GEN. LAWS ANN. § 12-28-3 (West 2006); S.C. CODE ANN. § 16-3-1515 (2003); 
Thirty-five of the thirty-eight capital states, ${ }^{57}$ as well as the military ${ }^{58}$ allow VIS during capital sentencing. Few states place substantive or procedural limits on the types and amount of victim impact evidence admissible. $^{59}$

In federal courts, the U.S. Code specifically allows for VIS in hearings to determine whether a death sentence is justified. ${ }^{60}$ According to the Federal Death Penalty Act of 1994 (FDPA), ${ }^{61}$ VIS and other evidence of effects on the victim and the victim's family can be used as non-statutory aggravating factors as long as one statutory aggravating factor exists. ${ }^{62}$ Federal prosecuting attorneys are merely required to notify the defendant as to what types of VIS will be used, although state courts do not have such requirements. ${ }^{63}$

S.D. Codified LAWS § 23A-28C-1 (2004); TENN. CODE ANN. §§ 40-35-207, -38-203 (West 2008); TEX. Code Crim. Proc. ANN. art. 56.03 (Vernon 2003); UtAH Code ANN. § 76-3-207 (West 2004); VT. STAT. ANN. tit. 13, § 7006 (West 2007); VA. CODE ANN. §§ 19.2-264.5, -299.1 (West 2007); WASH. Rev. CODE ANN. $\$ \$ 7.69 .020, .030$ (West 2007); W. VA. CODE ANN. $\$ \S 61-11 \mathrm{~A}-2,-3$ (West 2002); Wis. Stat. AnN. § 950.04 (West 2005); Wyo. Stat. AnN. §§ 7-21-101, -13-303 (West 2007). Alabama and Nevada do not provide for VIS from the family, but do allow statements from the victim. Ala. CODE § 15-23-73 (1995); Nev. Rev. Stat. ANN. § 176.145 (West 2000).

57. Ala. CODE $\S \S 13$ A-5-47(b) (1995), 15-23-72(2)(c) (2006); ARIZ. CONST. art. II, $\S$ 2.1(A)(7); Ark. Code AnN. § 5-4-602(4)(a)(iii) (West 2008); Cal. Penal Code, § 190.3 (West 2000); Colo. Rev. STAt. AnN. § 18-1.3-1201(1)(b) (West 2008); ConN. GEN. STAT. ANN. §§ 53a46d (West 2007), 54-220(a)(2) (West 2009); Del. CODE ANN. tit. 11, § 4331 (West 2006); FlA. STAT. ANN. § 921.143 (West 2001); GA. CODE ANN. § 17-10-1.2 (West 2003); IDAHO CODE ANN. § 19-5306 (West 2006); 725 Ill. CoMP. STAT. ANN. 120/3, 120/6 (West 2008); IND. CodE ANN. § 3550-2-9(e) (West 2004); Kan. Stat. AnN. §§ 74-7333 to -7338; Ky. ReV. STAT. ANN. § 421.520 (West 2006); LA. Code Crim. Proc. ANN. art. 905.2 (2008); MD. Code ANN., Crim. Proc. §§ 11401, -403 (West 2002); Mo. Rev. STAT. § 217.762 (1993); Mont. CODE ANN. § 46-18-112 (2009); Neb. Rev. Stat. AnN. § 29-2261 (West 2009); N.H. Rev. Stat. AnN. § 21-M:8-K(II)(P) (2007); N.M. Stat. ANN. § 31-26-4(G) (West 2003); N.C. GEN. STAT. § 15-A833 (2001); OHIO REV. CodE ANN. $\S 2930.02, .14,2947.051$ (West 2006); OKLA. STAT. ANN. tit. 22, §984.1 (West 2003); OR. ReV. STAT. ANN. §§ 137.013, 163.150(1)(a) (West 2003); 42 PA. Cons. STAT. ANN. § 9711 (West 2007); S.D. CODIFIED LAWS § 24-15A-43 (2004); TENN. CODE ANN. § 39-13-204(c) (West 2008); Tex. Code Crim. Proc. AnN. art. 37.07 § 3(a)(1) (Vernon 2003); Utah Code AnN. § 76-3207(2)(a)(iii) (West 2004); VA. CODE ANN. $\$ \$ 19.2-264.5,-299.1$ (West 2007); WASH. REV. Code ANN. §§ 10.95.060(3), .070 (West 2007); WYO. STAT. ANN. § 7-21-101 to -103 (West 2007).

58. MANUAL FOR COURTS-MARTIAL UNITED STATES $\S$ 1001(b)(4) (2008) (permitting introduction of victim-impact evidence in trials); § 1004(b)(2) (permitting introduction of such evidence in capital trials).

59. See John H. Blume, Ten Years of Payne: Victim Impact Evidence in Capital Cases, 88 CORNELL L. REV. 257, 268-76 (2003) (noting the wide array of jurisdictions and circumstances in which victim impact evidence is admissible). See generally Justin D. Flamm, Due Process on the "Uncharted Seas of Irrelevance": Limiting the Presence of Victim Impact Evidence at Capital Sentencing After Payne v. Tennessee, 56 WASH. \& LEE L. REV. 295, 296 (1999) (noting broad admission of victim impact evidence, especially among capital states).

60. 18 U.S.C. $\$ 3593$ (2006).

61. Id.

62. $\S 3593(\mathrm{c})$.

63. See Wayne A. Logan, Victim Impact Evidence in Federal Capital Trials, 19 FED. SENT'G REP. 5, 6 (2006). 
Trial courts have broad discretion as to the type and amount of VIS that are admissible. VIS are not regulated specifically by the Federal Rules of Evidence; instead, the Code sets out a test similar to both Federal Rule of Evidence 403 and the Supreme Court's test set out in Payne: "Information is admissible regardless of its admissibility under the rules governing admission of evidence at criminal trials except that information may be excluded if its probative value is outweighed by the danger of creating unfair prejudice, confusing the issues, or misleading the jury." $" 65$

This broad discretion exercised by trial judges has resulted in vast amounts of material being admitted in VIS. Upon review, the information admitted is rarely found to be prejudicial. No federal, ${ }^{66}$ and few state death sentences have been overturned as a result of unduly prejudicial VIS. ${ }^{67}$ For example, the failure of the FDPA to limit the number of VIS has resulted in multiple and sometimes repetitive testimonies for a single victim. ${ }^{68}$ In cases involving multiple victims, the court is free to allow testimony based on whatever number of witnesses it deems appropriate to show the harm or impact of the crime. $^{69}$ Additionally, although the FDPA refers only to testimony regarding the impact on the victim and the victim's family, ${ }^{70}$ both federal and state courts have failed to restrict such testimony to victims and family and have allowed other community members to make VIS. ${ }^{71}$

Trial courts' discretion in allowing VIS is not only limited to the amount of evidence; it extends to the scope of evidence admitted as well.

\footnotetext{
64. See infra Part II.D.

65. §3593(c).

66. See Logan, supra note 63, at 6 (as of a study done on Westlaw through 2006).

67. See, e.g., Wimberly v. State, 759 So. 2d 568, 574 (Ala. Crim. App. 1999) (reversing on other grounds but noting that admission of improper victim impact evidence would have, by itself, warranted a new sentencing); Clark v. Commonwealth, 833 S.W.2d 793, 796-97 (Ky. 1991) (ordering new trial due to improper statements of family's grief); State v. Bernard, 608 So. 2d 966, 973 (La. 1992) (remanding for lack of pretrial hearing regarding impact evidence admissibility); State v. Hightower, 680 A.2d 649, 662 (N.J. 1996) (finding defendant should have been granted mistrial after admission of prejudicial impact evidence).

68. See, e.g., United States v. Allen, 247 F.3d 741, 779 (8th Cir. 2001) (allowing eleven witnesses, including a former coworker, two bank employees, and the victim's ex-wife) vacated, Allen v. United States, 536 U.S. 953 (2002); United States v. Barnette, 211 F.3d 803, 818 (4th Cir. 2000) (allowing seven witnesses for a double murder).

69. See United States v. McVeigh, 153 F.3d 1166, 1216 (10th Cir. 1998) (allowing thirty-eight witnesses to testify about the impact of the Oklahoma City bombing).

70. $\S 3593(\mathrm{a})$

71. See, e.g., United States v. Nelson, 347 F.3d 701, 712-13 (8th Cir. 2003) (allowing a teacher, neighbor, and classmate to testify); United States v. Bernard, 299 F.3d 467, 478 (5th Cir. 2002) (allowing friend and former coworker); Allen, 247 F.3d at 779 (allowing a coworker and former coworker); United States v. Paul, 217 F.3d 989, 995 (8th Cir. 2000) (allowing coworker).
} 
The FDPA provides that VIS may refer to "the effect of the offense on the victim and the victim's family ...."72 Courts have included in this definition evidence regarding personal traits of victims, finding such evidence shows "each victim's uniqueness as an individual human being....,73 The FDPA does put forth a requirement, which many states lack, that jurors certify that the background information of the victim and the defendant did not influence the decision to impose a capital sentence. ${ }^{74}$ Federal and most state courts have, however, refused to allow VIS to include evidence of other crimes, ${ }^{75}$ or opinions regarding the defendant and whether death should be imposed. ${ }^{76}$ Yet, even with these limitations, vast amounts of prejudicial information are allowed, resulting in a need for stricter limitations on what can be admitted in VIS - especially when music is involved.

\section{Case History}

The United States Supreme Court first looked at the general use of VIS during the sentencing phase of a capital trial in Booth v. Maryland in 1987. ${ }^{77}$ Booth was convicted of murdering an elderly couple in their Baltimore home, leaving the bodies to be discovered by their son two days later. ${ }^{78}$ During the penalty phase the government introduced VIS from the son, daughter, son-in-law, and granddaughter, and Booth was sentenced to death. ${ }^{79}$ The family's statements described the personal qualities of the victims, the impact the deaths had on the family and community, and the emotional and personal problems the family suffered as a result of the deaths. ${ }^{80}$ The testimony regarded Booth as someone who could " "[n]ever be rehabilitated" "and described the victims as being " "butchered like animals." "81 Defense counsel moved to exclude the statements as so irrelevant and unduly inflammatory that it violated the

\footnotetext{
72. $\S 3593(a)$.

73. Payne v. Tennessee, 501 U.S. 808, 823 (1991) (emphasis and internal quotations omitted).

74. §3593(f).

75. See United States v. Sampson, 335 F. Supp. 2d 166, 193 (D. Mass. 2004) (stating that allowing VIS on prior offenses would "create too great a risk that the jury would be influenced by sympathy and passion"). But see State v. Robinson, 451 S.E.2d 196, $204-05$ (N.C. 1994) (allowing VIS from child of defendant's previous murder victim).

76. See Payne, 501 U.S. at 830 n.2 (1991) (upholding Booth's provision that characterizations and opinions about the crime, the defendant, and the sentence may not be included in VIS).

77. 482 U.S. 496, 496-97 (1987), overruled by Payne v. Tennessee, 501 U.S. 808 (1991).

78. Id. at 498 .

79. Id. at 499 .

80. Id.

81. Id. at 500
} 
Eighth Amendment's prohibition against cruel and unusual punishment. ${ }^{82}$ The Court, in a five-to-four decision, agreed, holding that the information provided in the VIS was irrelevant and created a "constitutionally unacceptable risk" that the jury would act arbitrarily and capriciously in determining the sentence. ${ }^{83}$

The Booth decision determined that when VIS are involved, the focus is not on the defendant, but on the victim's character and reputation-factors that may be irrelevant to the culpability of the defendant and circumstances of which the defendant may not even be aware. $^{84}$ Families are able to and will express their grief in different ways, and one family's ability to convey a stronger message of grief than another has nothing to do with whether one defendant should receive a stronger sentence than another. ${ }^{85}$ Additionally, defendants should not be sentenced according to the victim's positive involvement in the community. ${ }^{86}$ The Court noted that emotional opinions from family members could incite the jury and distract it from deciding the case on relevant evidence ${ }^{87}$ as a result, the Court barred the use of VIS during the sentencing phase of capital murder trials unless directly relating to the crime's circumstances. ${ }^{88}$

The Supreme Court reiterated this opinion in South Carolina $v$. Gathers, ${ }^{89}$ finding that prosecutors' statements focusing on victim characteristics were as dangerous as those discussed in Booth and equally likely to result in arbitrary and capricious imposition of the death penalty. $^{90}$ The Court found only testimony relating to the "blameworthiness" of a defendant to be relevant and permissible during sentencing. ${ }^{91}$

82. See U.S. CONST. amend. VIII ("Excessive bail shall not be required, nor excessive fines imposed, nor cruel and usual punishments inflicted.").

83. Booth, 482 U.S. at $502-03$.

84. Id. at $504-05$.

85. See id. at 505-06 ("Certainly the degree to which a family is willing and able to express its grief is irrelevant to the decision whether a defendant, who may merit the death penalty, should live or die." (citing Booth v. State, 507 A.2d 1098, 1129 (Md. 1986) (Cole, J., concurring in part and dissenting in part))).

86. See id. at 506 ("[There is no] justification for permitting [a sentencing] decision to turn on the perception that the victim was a sterling member of the community rather than someone of questionable character.")

87. Id. at 508 .

88. See id. at 507,507 n.10 (generally disallowing VIS during capital sentencing but recognizing that "[s]imilar types of information may well be admissible because they relate directly to the circumstances of the crime").

89. 490 U.S. 805 (1989), overruled by Payne v. Tennessee, 501 U.S. 808 (1991).

90. Id. at 811 .

91. Id. at 810 (citing Booth v. Maryland, 482 U.S. 496, 504 (1987)). 
The Supreme Court reversed both Booth and Gathers in Payne v. Tennessee, ${ }^{92}$ deciding there should be no per se bar prohibiting VIS in capital sentences. ${ }^{93}$ Payne was convicted of two counts of first-degree murder and an assault with intent to commit murder in the first degree and was sentenced to death. ${ }^{94}$ During his sentencing, the State presented testimony by a family member who described how the events affected the surviving victim, a four-year-old boy. ${ }^{95}$ She articulated the child's confusion as to why his mother and sister were no longer around. ${ }^{96}$ The Supreme Court upheld the admission of the testimony, finding that such information is only barred if it is "so unduly prejudicial that it renders the trial fundamentally unfair." 97

The Payne Court saw VIS as "simply another form or method [used by a state to inform] the sentencing authority about the specific harm caused by the crime in question." 98 The Court reasoned that such statements serve a legitimate purpose by exhibiting the "defendant's moral culpability and blameworthiness," from offering "a quick glimpse of the life [the defendant] chose to extinguish," while the defendant is able to enter mitigating evidence with virtually no limits. ${ }^{100}$ VIS are entered in part to show each victim's " uniqueness as an individual human being,",101 and statements meeting this purpose should be admitted as long as the evidence is not unduly prejudicial, in which case the defendant can seek remedy under the Fourteenth Amendment's due process clause. ${ }^{102}$

92. 501 U.S. 808, at 830 (1991).

93. Id. at 827 .

94. Id. at 811

95. Id. at $814-15$ (“'He cries for his mom. He doesn't seem to understand why she doesn't come home. And he cries for his sister Lacie. He comes to me many times during the week and asks me, Grandmama, do you miss my Lacie. And I tell him yes. He says, I'm worried about my Lacie."”).

96. Id.

97. Id. at 825. See also infra Part II.D (defining the test).

98. Payne, 501 U.S. at 825 .

99. Id.

100. Id. at 822 (citing Mills v. Maryland, 486 U.S. 367, 397 (1988) (Rehnquist, C.J., dissenting)).

101. Id. at 823 .

102. Id. at 825 . The Fourteenth Amendment to the United States Constitution provides in part: No State shall make or enforce any law which shall abridge the privileges or immunities of citizens of the United States; nor shall any State deprive any person of life, liberty, or property, without due process of law; nor deny to any person within its jurisdiction the equal protection of the laws.

U.S. CONST. amend. XIV, $\S 1$. 
The test put forth in Payne gives courts little direction as to how to limit evidence offered as VIS. ${ }^{103}$ Payne's instructions allowing evidence of each victim's "uniqueness as an individual human being""104 and informing "the sentencing authority about the specific harm caused by the crime in question" 105 are far from specific. The authority to admit VIS is left very much to the trial court's discretion, leaving open the possibility for abuse.

The wide discretion offered to courts is evidenced by the various attempts to apply Payne specifically to VIS involving music. Such cases have reached varying results, and a universal application of the standard is needed - one that denies admission of music during VIS. Although some VIS include music only to exhibit a victim's specific talent or in other ways that supplement live testimony, ${ }^{106}$ the vast majority of VIS involving music are in cases where a victim has died and the prosecution offers a photo montage of the victim's life. ${ }^{107}$

The first widely cited case applying Payne's guidelines to the admission of music during VIS was Salazar v. State, ${ }^{108}$ decided in 2002. There, the Texas Court of Criminal Appeals rejected a picture montage set to music. ${ }^{109}$ The defendant, a sixteen-year-old special-education student, was convicted of murder and sentenced to death. ${ }^{110}$ During sentencing, the state showed a video tribute of the victim consisting of 140 photographs set to the music of "Storms in Africa" and "River" by Enya and Celine Dion's "My Heart Will Go On."111 The court held that admitting the video was reversible error as it was "very lengthy, highly emotional, and barely probative."

\footnotetext{
103. See infra Part II.D.

104. Payne, 501 U.S. at 823.

105. Id. at $824-25$. nationally known). App. 2006)

108. 90 S.W.3d 330 (Tex. Crim. App. 2002)

109. Id. at 332 .

110. Id.

111. Salazar, 90 S.W.3d at 333.

112. Id. at 338 .
}

106. See, e.g., State v. Leon, 132 P.3d 462, 466 (Idaho Ct. App. 2006) (admitting a video with background music illustrating the victim with her children); Whittlesey v. State, 665 A.2d 223, 230 (Md. 1995) (admitting a video of the victim playing piano, a skill for which the victim was

107. All but one case discussed in this comment occurred when the victim had died. In Petruccelli v. State, the victim survived but suffered severe mental and physical disabilities, and music was used during a tape depicting the impact on her life. 184 S.W.3d 747, 747-48 (Tex. Crim. 
alone were enough to require reversal, ${ }^{113}$ the background music "greatly amplifie[d] the prejudicial effect of the original error."114

A district court in Massachusetts refused to allow a similar video tribute in United States v. Sampson. ${ }^{115}$ The defendant in Sampson was convicted of murdering several people, including a young college student who had picked up the hitchhiking defendant, and the jury returned a verdict of death. ${ }^{116}$ The government sought to introduce a memorial video of the college victim during the sentencing. The video was made in preparation of a memorial service, lasted twenty-seven minutes, included over 200 photographs, and was set to background music of The Beatles and James Taylor. ${ }^{117}$ The court refused to admit the video, finding that any probative value was outweighed by the danger of unfair prejudice, which could result in the jury reaching a sympathetic verdict instead of one based on reason. ${ }^{118}$ Although the court admitted that the tape would have been unduly prejudicial even without the background music, the "evocative accompanying music [together with] the videotape's images would have inflamed the passion and sympathy of the jury." "119

In People v. Kelly, ${ }^{120}$ the defendant was convicted of murdering a nineteen-year-old girl by becoming her personal trainer, luring her into his home, and stabbing her to death with a pair of scissors. ${ }^{121}$ The jury returned a verdict of death. ${ }^{122}$ During the sentencing phase of the trial, the California Supreme Court allowed a twenty-minute video montage prepared by the victim's mother consisting of photographs and videos depicting the victim's life. ${ }^{123}$ The victim's mother narrated during the playing of the tape while the music of Enya played in the background. ${ }^{124}$ The court found the tape "properly focused on [the victim's] life and the pain her death caused her family and friends." ${ }^{25}$ The court did,

\footnotetext{
113. The pictures spanned the victim's entire lifetime and there were numerous photos of the victim as a smiling child. The court found these to be severely prejudicial as it appeared as though the defendant had murdered a child instead of an adult. See id. at 337.

114. Id. at 339 .

115. 335 F. Supp. 2d 166 (D. Mass. 2004).

116. Id. at 175 .

117. Id. at 191

118. Id.

119. Id. at $192-93$.

120. 171 P.3d 548 (Cal. 2007), cert. denied 129 S. Ct. 564 (2008).

121. Id. at 553-55.

122. Id. at 548 .

123. Id. at 570 .

124. Id.

125. Id. at 568 .
} 
however, recognize an irrelevant aspect of the video-the background music. ${ }^{126}$ Although recognizing music as a whole is not per se impermissible (there was no error in including a segment of the victim singing "You Light Up My Life" as a solo at school), ${ }^{127}$ the court found the background music irrelevant, even though the mother testified that it was some of the victim's favorite music. ${ }^{128}$ Including the music did nothing but add an emotional element to the video, yet the court still did not find including the music to be so prejudicial as to warrant a reversal in light of the trial as a whole. ${ }^{129}$

Both state and federal courts have allowed the use of music during photo montages under Payne's rationale that the pictures show the victim's uniqueness and give the sentencing authority a better view of the harm caused. Even though the addition of background music to these pictures is not probative and it is the pictures themselves that are relevant, lower courts have been inconsistent in their analysis of when music becomes unduly prejudicial. The United States Supreme Court recently had turned down a chance to clarify its view on the prejudice of such videos when it chose not to review the decision in Kelly $v$. California. ${ }^{130}$ Justice Stevens recognized the need to clarify Payne to the lower courts:

[Payne's test] represents the beginning and end of the guidance we have given to lower courts considering the admissibility of victim impact evidence....

... [L]ower courts throughout the country have largely failed to place clear limits on the scope, quantity, or kind of victim impact evidence capital juries are permitted to consider.

$\cdots$

... [T] he Court has a duty to consider what reasonable limits should be placed on its use. ${ }^{131}$

\footnotetext{
126. Id. at 571 .

127. Id. at $570-71$.

128. Id. at $571-72$.

129. Id.

130. 129 S. Ct. 564 (2008).

131. Id. at 566-67 (2008) (Stevens, J., respecting the denial of the petitions for writs of certiorari).
} 


\section{The Current Standard}

Presently, the allowance of VIS is governed by the test set out in Payne. This standard, however, leaves great discretion to the trial courts, which have repeatedly allowed highly prejudicial music during VIS. A court's real duty is to use its discretion to ensure that the evidence's probative value outweighs the sincere danger of unfair prejudice-which could inflame the jury's passions and, in the words of Payne, "risk a verdict impermissibly based on passion, not deliberation."132 By allowing background music during VIS, courts are failing in this task.

\section{Payne's Test}

Payne allows admission of information relating to "each victim's "uniqueness as an individual human being" and "informing the sentencing authority about the specific harm caused by the crime in question."133 The Court's inclusion of this standard places some limits on a trial court's authority to admit VIS. VIS must first meet one of these two goals, then they are admissible as long as they are not "so unduly prejudicial that it renders the trial fundamentally unfair," "134 in which case the Fourteenth Amendment prohibits admission. ${ }^{135}$

The background music in VIS does not establish either goal; it is the actual testimony offered during VIS that describes the individual's uniqueness and informs those listening of the harm. As a result, background music itself is not relevant evidence. Such music, however, typically only accompanies photos depicting deceased victims, and courts are generally willing to admit a number of photos of the victim to show the victim's individuality. ${ }^{136}$ When irrelevant evidence is offered along with any sort of relevant testimony, ${ }^{137}$ the court then must analyze

\footnotetext{
132. Payne v. Tennessee, 501 U.S. 808, 836 (1991) (Souter, J., concurring).

133. Id. at 823,825 (emphasis in original).

134. Id. at 825

135. See id.; see also supra text of note 102 (quoting the Fourteenth Amendment).

136. See supra Part II.C (discussing admission of photo montages set to background music as victim impact evidence).

137. The Payne Court left it to the states to decide for themselves what VIS are relevant, suggesting the admission of VIS should be decided under the same standards as other evidentiary decisions regarding relevance:

A State may legitimately conclude that evidence about the victim and about the impact of the murder on the victim's family is relevant to the jury's decision as to whether or not the death penalty should be imposed. There is no reason to treat such evidence differently than other relevant evidence is treated.

Payne, 501 U.S. at 827 . The lack of a bright-line rule for relevance often requires a case-by-case
} 
the entire statement under the Payne standard. Trial courts must thus focus on whether the inclusion of the irrelevant evidence is "so unduly prejudicial that it renders the trial fundamentally unfair."138

The Tenth Circuit in United States v. McVeigh explained the duty of the jury:

Payne allows the introduction of victim impact testimony to aid the jury in making a "reasoned moral response" when imposing sentence upon a defendant convicted of a capital offense. First, the sentence must be the result of a reasoned decision. The evidence must not be so unduly prejudicial that its admission allows emotion to overwhelm reason. Second, the sentence must be based on moral considerations. Because the consequences of the crime are an important ingredient in the moral equation, the government can present testimony demonstrating the harm caused by the defendant's actions. Third, the sentence must reflect the jury's judgment. The jury must balance all of the relevant mitigating and aggravating factors in determining an appropriate sentence.

\section{Defining the Standard}

To truly understand how to apply Payne's test, its terminology must be defined. Courts have some guidelines to follow when deciding if evidence in general is too prejudicial. The official comment to Rule 403 of the Federal Rules of Evidence, which excludes relevant evidence that is outweighed by unfair prejudice, defines "unfair prejudice" as "an undue tendency to suggest decision on an improper basis, commonly, though not necessarily, an emotional one." ${ }^{\text {"140 }}$ Although Rule 403 does not govern admission of VIS, the Payne test is strikingly similar. As previously discussed, music has an effect on emotion, which, in turn, affects decision-making. Because music has a proven tendency to affect a juror's decision-making, it should be deemed prejudicial, by the very definition of undue prejudice.

Previously, courts have held that VIS involving opinions regarding the defendant or possible sentences are unduly prejudicial. It is too

\footnotetext{
determination. See, e.g., State v. Nesbit, 978 S.W.2d 872, 891 (Tenn. 1998) ("[T]here is no brightline test, and the admissibility of specific types of victim impact evidence must be determined on a case-by-case basis.").

138. Payne, 501 U.S. at 825.

139. United States v. McVeigh, 153 F.3d 1166, 1217 (10th Cir. 1998) (citation omitted).

140. FED. R. EVID. 403 advisory committee's note. Similarly designed state rules of evidence add to this standard. See, e.g., PA. R. EvID. 403 (defining unfair prejudice as "a tendency to suggest [a] decision on an improper basis or to divert the jury's attention away from its duty of weighing the evidence impartially").
} 
difficult for jurors to ignore such inflammatory remarks; additionally, opinions are irrelevant as they do not address either purpose of VIS. For example, an Oklahoma court found "[s]tatements that the defendant acted 'like [a] blood thirsty animal[],", "“a parasite', and a 'murderous animal" when he "butchered [the victim] like an animal"" to be unduly prejudicial. ${ }^{141}$ Although the court found the statements unduly prejudicial, it reversed on other grounds and did not address whether the existence of prejudice violated due process, stating only that " $[t]$ he more a jury is exposed to the emotional aspects of a victim's death, the less likely their verdict will be a 'reasoned moral response' to the question whether a defendant deserves to die; and the greater risk a defendant will be deprived of Due Process." 142

It is equally frustrating to define the standard "fundamentally unfair." The Supreme Court has even had trouble defining the term, stating that fundamental fairness is "a requirement whose meaning can be as opaque as its importance is lofty." "43 Deciding what makes an entire trial fundamentally unfair is especially challenging, as it depends heavily on the particular facts of each individual case. Apart from its difficulty, courts may be reluctant to set a firm definition because it would severely limit appellate courts' discretion to decide cases challenging their fundamental fairness. ${ }^{144}$

Courts have established that analyzing a due process claim for fundamental fairness requires considering the challenged conduct in relation to the trial as a whole. The Payne Court similarly suggested this tactic by using Darden v. Wainwright ${ }^{145}$ to illustrate how to analyze due process claims. ${ }^{146}$ The defendant in Darden argued that the prosecution's closing remarks rendered his conviction fundamentally unfair, thus depriving his sentencing of any Eighth Amendment protection. ${ }^{147}$ The Supreme Court evaluated the comments in light of the trial as a whole, considering other relevant factors such as the trial court's instructions to the jury and the other overwhelming evidence of

141. Conover v. State, 933 P.2d 904, 920-21 (Okla. Crim. App. 1997).

142. Id. at 921 (quoting California v. Brown, 479 U.S. 538, 545 (1987)).

143. Lassiter v. Dep't of Soc. Servs., 452 U.S. 18, 24 (1981).

144. See United States v. Rivera, 900 F.2d 1462, 1477 (10th Cir. 1990) ("As a result, the constitutional guarantee of a fundamentally fair trial cannot be defined with reference to particularized legal elements, which would limit the discretion of courts to determine whether a trial was fundamentally unfair. Precisely because a fundamental-fairness analysis is not subject to clearly definable legal elements, however, we must approach such analysis with considerable selfrestraint.").

145. 477 U.S. 168 (1986)

146. See Payne v. Tennessee, 501 U.S. 808, 825 (1991) (citing Darden, 477 U.S. at 179-83).

147. Darden, 477 U.S. at $178-79$. 
the defendant's guilt. ${ }^{148}$ Using Darden as a guide, the Payne Court established that fundamental fairness questions over VIS should use a similar rationale, and fundamental fairness questions should be decided in view of the trial as a whole.

\section{ANALYSIS}

Allowing music in VIS stretches the Payne decision too far. Music does not meet either of the VIS objectives set out in Payne; as such, it is irrelevant. Courts currently applying the Payne standard repeatedly admit that including music is prejudicial, but have been unwilling to find its admission fundamentally unfair. As discussed above, music's emotional effects reveal its highly prejudicial influence on emotion, which, in turn, affects decision-making. This added emotion creates a great danger of arbitrary decision-making. After realizing this risk and applying other rationales courts use when deciding to admit evidence, it is clear that music cannot be admitted. Prohibiting the use of music is necessary now and will only become more so in the future as advancements in technology make using music easier and more common. Adding music to already emotional VIS does nothing but play on juror emotions and interfere with a jury's ability to make a decision on reason and merits. The result: an unacceptably high risk of arbitrary and unreliable decisions, denying defendants a fundamentally fair sentencing.

\section{A. Courts Applying Payne to Music Produce Inconsistent Results}

Because the Supreme Court has not addressed VIS admission in capital trials since Payne, lower state and federal courts have since been applying the Payne standard to VIS. Cases specifically involving background music have produced varying decisions, even in those cases involving similar facts. ${ }^{149}$ These various results demonstrate the need for a new and universal application of Payne's test when background music is involved, and the prejudicial impact of such music demands that courts deny its admission and protect defendants from such arbitrary results.

Courts applying the Payne standard to cases involving musical VIS have reached varying conclusions, even failing to uniformly rule regarding music of the same artist. The California Supreme Court, in

148. Id. at $181-82$.

149. See supra Part II.C. 
People v. Kelly, ${ }^{150}$ allowed a twenty-minute photo montage that included the music of Enya. ${ }^{151}$ In United States $v$. Sampson, ${ }^{152}$ a Massachusetts district court viewed a similar video lasting twenty-seven minutes and set to the music of The Beatles and James Taylor, and determined it to be unduly prejudicial. ${ }^{153}$ And the Texas Court of Criminal Appeals recognized the prejudice of allowing the music of Celine Dion and Enya to accompany a picture montage in Salazar v. State. ${ }^{154}$ Because courts are applying a test based on discretion, some variation can be expected. However, correct application of the Payne standard should never result in admission of music during VIS because music in VIS is always irrelevant, unduly prejudicial, and fundamentally unfair.

\section{B. The Emotions Created by Music Cause Prejudicial Emotional Decisions That Result in a Fundamentally Unfair Trial}

The United States Supreme Court has made clear its position that sentencing decisions should be based on reason. "[P] unishment should be directly related to the personal culpability of the defendant. Thus, the sentence imposed . . . should reflect a reasoned moral response ... rather than mere sympathy or emotion." 155 Yet, by allowing music during sentencing, courts risk the inevitable result that an irrelevant and prejudicial factor will influence juror decisions and cause arbitrary results. Courts themselves have admitted that music is prejudicial, but somehow fail to find that this amounts to a fundamentally unfair sentencing. ${ }^{156}$ When music is played during sentencing, its prejudicial influences invite the jury to make arbitrary decisions, which are

\footnotetext{
150. 171 P.3d 548 (Cal. 2007), cert. denied, 129 S.Ct. 564 (2008).

151. Id. at 570 .

152. 335 F. Supp. $2 d 166$ (D. Mass. 2004).

153. Id. at 191 .

154. 90 S.W.3d 330, 333, 338 (Tex. Crim. App. 2002)

155. California v. Brown, 479 U.S. 538, 545 (1987) (O’Connor, J., concurring) (emphasis in original). Other opinions have specifically warned against arbitrary decisions in death penalty cases. See Gardner v. Florida, 430 U.S. 349, 358 (1977) ("It is of vital importance to the defendant and to the community that any decision to impose the death sentence be, and appear to be, based on reason rather than caprice or emotion.”); Gregg v. Georgia, 428 U.S. 153, 189 (1976) (“[W]here discretion is afforded a sentencing body on a matter so grave as the determination of whether a human life should be taken or spared, that discretion must be suitably directed and limited so as to minimize the risk of wholly arbitrary and capricious action.").

156. See United States v. Sampson, 335 F. Supp. 2d 166, 192-93 (D. Mass. 2004) (finding that "evocative accompanying music [together with] the videotape's images would have inflamed the passion and sympathy of the jury"); Salazar v. State, 90 S.W.3d 330, 339 (Tex. Crim. App. 2002) (reversing for prejudice of admitted photos, but finding that the background music "greatly amplifie[d] the prejudicial effect of the original error").
} 
forbidden by the Eighth Amendment. ${ }^{157}$ As the Supreme Court warned, "[i]t would be very difficult to reconcile a rule allowing the fate of a defendant to turn on the vagaries of particular jurors' emotional sensitivities with our longstanding recognition that, above all, capital sentencing must be reliable, accurate, and nonarbitrary."

Jurors are expected to decide based on evidence and reason, especially when making a decision involving life or death. The Supreme Court has noted, "[i]t is of vital importance to the defendant and to the community that any decision to impose the death sentence be, and appear to be, based on reason rather than caprice or emotion." 159 Yet, in highly emotional trials-especially when making sentencing decisionseliminating natural human emotions could prove to be a difficult task. As a result, numerous studies have focused on mock jurors in the trial setting to see exactly what effect emotion has on decision-making. ${ }^{160}$

Emotion can be defined as realized or unrealized "feelings, cognitions, and actions or inclinations to act." "161 Emotions typically serve to signal environmental changes and to provide guidance when choosing and evaluating competing goals and morals. ${ }^{162}$ As such, it is only natural for emotions to come into play when making a decision. Feigenson and Park established three ways emotion can affect judgment in the legal realm. Emotions can affect the way one processes information in general, changing from "bottom-up" decisions based on data to "top-down or schema-driven" evaluations. ${ }^{163}$ Thus, instead of deciding on a factual basis, emotions such as anger may cause jurors to use stereotypes to find defendants liable for a stereotypical offense. ${ }^{164}$ The effect an emotion has on processing depends on the emotion itself. "Certain" emotions like anger, disgust, and happiness lead to a perceived confidence that can cause jurors to process information less systematically-resulting in consideration of fewer factors and an inability to distinguish strong from weak arguments. ${ }^{165}$ Thus, the

157. See U.S. CONST. amend. VIII ("Excessive bail shall not be required, nor excessive fines imposed, nor cruel and unusual punishments inflicted.").

158. Saffle v. Parks, 494 U.S. 484, 493 (1990).

159. Gardner v. Florida, 430 U.S. 349, 358 (1977).

160. Although these studies focus on jurors in the guilt phase of a trial, the implications can be carried over to the sentencing phase.

161. Neal Feigenson \& Jaihyun Park, Emotions and Attributions of Legal Responsibility and Blame: A Research Review, 30 LAW \& HuM. BeHAV. 143, 144 (2006).

162. Id.

163. Id.

164. Id.

165. Id. at $147-48$. 
decision is less thought-out or thoroughly reviewed. "Uncertain" emotions such as hope, anxiety, and some types of sadness will not have the same result. ${ }^{166}$ Additionally, angry individuals rationalize differently than saddened individuals. ${ }^{167}$

Emotions can also bias judgment by directing jurors through a "mood-congruency effect," which causes people to interpret information depending on emotion. ${ }^{168}$ Jurors feeling negative emotions will perceive ambiguous events negatively, recall more negative information, and be negatively biased when asked to make a judgment regarding that event. ${ }^{169}$ This effect can be reduced if the decision-maker recognizes the bias and makes a sufficient effort to correct it; ${ }^{170}$ however, this process may result in overcorrection, and a result in the opposite direction. ${ }^{171}$

Research has established that emotions do influence decision-making and that different emotions do so differently. Although there are many chances during a trial for emotion to affect judgment, ${ }^{172}$ many studies have used mock-juror research to specifically study how jurors place blame after hearing VIS. In mock-juror research, those listening to VIS perceive greater suffering than those not exposed to VIS. ${ }^{173}$ This results in longer sentences to those defendants causing high amounts of suffering and lower sentences to defendants causing less. ${ }^{174}$ Similarly, in death penalty cases, participants hearing VIS from the family voted for

\footnotetext{
166. Id. at 148 .
}

167. Bryan Myers et al., Psychology Weighs in on the Debate Surrounding Victim Impact Statements and Capital Sentencing: Are Emotional Jurors Really Irrational?, 19 FED. SENT'G REP. 13, 16 (2006). Angry individuals tend to make less-rational dispositional attributions (view the person as at fault) while saddened individuals seem to make more rational situational attributions (view the situation as at fault) when placing blame. $I d$.

168. Feigenson \& Park, supra note 161 , at $144-45$.

169. Id.

170. Id. at 149 (citing Richard E. Petty \& Duane T. Wegener, Flexible Correction Processes in Social Judgment: Correcting for Context-Induced Contrast, 29 J. EXPERIMENTAL SOC. PSYCHOL. 137 (1993); Duane T. Wegener \& Richard E. Petty, The Flexible Correction Model: The Role of Naïve Theories of Bias in Bias Correction, 29 ADVANCES IN EXPERIMENTAL SOC. PSYCHOL. 141 (1997)).

171. Id. (citing Leonard Berkowitz et al., Some Conditions Affecting Overcorrect ion of the Judgment-Distorting Influence of One's Feelings, in FEELING AND THINKING: THE ROLE OF AFFECT IN SOCIAL COGNITION 131 (Joseph P. Forgas ed. 2000)).

172. The theory of "affect infusion" suggests that trials produce tendencies for emotions to influence judgments. This theory asserts that emotions have a higher influence on judgments during constructive information processing (using nondirected search strategies or cognitive elaboration to find a solution, as when trying to decide why an individual may have committed a crime) rather than during directed processing (using a predetermined method, as when trying to recall someone's name). See Myers \& Greene, supra note 35, at 501.

173. Myers et al., supra note 167 , at 15.

174. Myers \& Greene, supra note 35, at 497. One should note that this study involved VIS from the victims themselves, and not from third parties. 
the death penalty $51 \%$ of the times, while only $20 \%$ did so when no VIS were present. ${ }^{175}$ It is also interesting to note another study showing that jurors receiving no VIS tended to give longer sentences than those who heard VIS indicating there was only mild harm - suggesting that jurors expect some degree of suffering from victims and that VIS are most influential when the suffering exceeds those expectations. ${ }^{176}$ Thus, if a jury expects a certain amount of grief from a family, but the VIS use music and amplify the level of sadness, the result in those cases will be harsher punishment that is not based on reason, but on emotion.

This is not to say that emotion should have no place in a trial. Emotional witnesses provide cues to jurors as to how they should feel, and studies show that individuals witnessing strong emotional displays can become emotional themselves. ${ }^{177}$ In some cases jurors may empathize with witnesses just from hearing descriptions of emotional suffering but still remain able to set emotions aside when it is time to reach a decision. ${ }^{178}$ Unfortunately, it is difficult, if not impossible, to assess whether sentences are imposed rationally or by emotions alone. ${ }^{179}$ Judgments based on emotion alone are obviously prejudicial; however, reasoned judgments may be accompanied by emotion without introducing prejudice. ${ }^{180}$ Alternatively, emotion from witnesses may in some cases add to a juror's rational assessment if he reasons that greater harm and suffering should result in harsher punishment. ${ }^{181}$

How can decision-makers experiencing emotion reduce bias? Research indicates that decision-makers who are "(i) aware of the unwanted influence; (ii) motivated to correct the bias; (iii) aware of the magnitude and direction of the bias; and (iv) able to adjust the response appropriately" can successfully correct the effects of emotion. ${ }^{182}$ Unfortunately, ideal jurors capable of this are unlikely to exist at every trial. Many jurors are unaware of the influence, and those who are aware most likely do not know how to successfully counter its effectsresulting in bias from overcorrection. ${ }^{183}$

The judicial system is structured to help keep jurors on track and away from emotional decisions. Careful and accurate jury

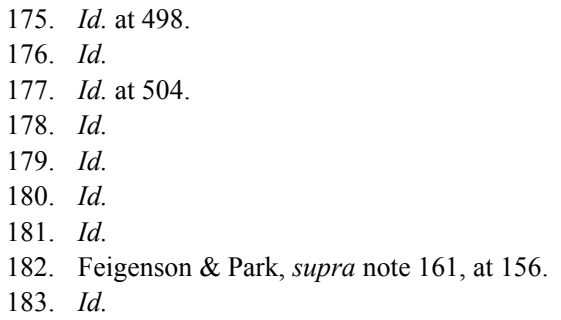


instructions, ${ }^{184}$ jurors who feel accountable for their decisions, ${ }^{185}$ and the desire to avoid perceived injustice can help attenuate incidental emotional influences. ${ }^{186}$ Additionally, group deliberation and delays between hearing testimony and deliberation may help lessen emotional influence. $^{187}$

However, when it comes to sentencing judgments by juries, it is the courts themselves that could have the greatest impact on reducing emotional judgments by limiting VIS in scope and amount, excluding victim opinions of the defendant or the crime, and providing jurors with instructions that explain the purpose and function of VIS. ${ }^{188}$ Courts could additionally take on the responsibility of privately viewing all evidence offered to decide whether admission would prevent a fundamentally fair trial. ${ }^{189}$ Some courts even recognize that prosecutors may play a role in preventing misuse of emotional VIS. As the Georgia Supreme Court stated:

I urge district attorneys to cautiously approach the use of such victim impact evidence. It benefits neither the victim, the victim's family, nor the public if successful advocacy results in the admission of irrelevant, prejudicial and inflammatory evidence which will then require new sentencing trials and further unduly delay the finality of death penalty cases.

Unfortunately, a revolution in the admission of prejudicial VIS will come not from the prosecution, but from the courts themselves. Courts need to adopt an application of the Payne standard that prohibits music in VIS and accounts for the highly prejudicial effect music has on emotions and decision-making. This is necessary to ensure a just sentencing.

Courts must consider evidence's prejudicial effect when considering admission. Irrelevant background music is highly likely to affect the jury in an irrational and prejudicial way. Research indicates music can actually create new emotions, or can amplify those already existing. ${ }^{191}$ Adding more emotion to VIS is dangerous, as VIS are highly emotional

\footnotetext{
184. Id. at 156 .

185. Id. at 147,156 .

186. Id. at 147 .

187. See Myers et al., supra note 167 , at 18 (stating that "in the research we have addressed, none of the studies investigated the effects of group deliberation on these emotions or the effects of an extended delay").

188. Myers \& Greene, supra note 35, at 506-09.

189. United States v. Sampson, 335 F. Supp. 2d 166, 187 (D. Mass. 2004).

190. Livingston v. State, 444 S.E.2d 748, 754 (Ga. 1994) (Fletcher, J., concurring).

191. See supra Part II.A.
} 
in and of themselves. Allowing emotional music will do nothing but add more unneeded emotion to an already highly emotional time, making jurors more likely to base their decisions on factors other than the merits. Emotional jurors result in arbitrary decisions, the very result the United States Supreme Court cautioned courts to avoid.

\section{Other Considerations for Not Admitting VIS Involving Music}

Courts that have faced a decision of whether or not to admit music have included a number of factors in their analyses, and by looking at what courts have thought important, one can see that music is not fit for admission. The Texas Court of Criminal Appeals suggested a four-factor test for courts to apply when trying to make admission decisions under Payne's admissibility test. The proposed factors include (1) the evidence's probative value, (2) the potential to affect the jury in an irrational and unforgettable way, (3) the time needed to develop the evidence, and (4) the proponent's need for the evidence to be admitted. ${ }^{192}$ These factors, among others, can likewise apply when analyzing the inclusion of background music in VIS.

\section{Probative Value}

Prosecutors cannot argue that background music adds any probative value to VIS. In fact, many courts discussing the admission of background music have ruled that its existence is irrelevant to the issues at hand. ${ }^{193}$ Showing a victim's uniqueness or details of the specific harm could be effectively communicated through spoken testimony or even pictures. The proponents of VIS will most likely use live witnesses to establish proper foundation; there is no reason why these live witnesses could not testify to any details of the victim or the harm caused. Because music lacks any probative value, there is no useful factual information that music can provide. As such, prohibiting music will not deprive the State of any right afforded by VIS - the jury will still hear of all the information pertaining to the victim's individuality and the harm caused,

192. Salazar v. State, 90 S.W.3d 330, 337 (Tex. Crim. App. 2002).

193. See, e.g., United States v. Reveles, No. ACM 29029, 1993 WL 135864, at *8 (A.F.C.M.R. April 27, 1993) (refusing to allow music or singing in the background of video); People v. Zamudio, 181 P.3d 105, 136 (Cal. 2008) (excluding a videotape's audio portion, finding it unduly prejudicial and inappropriate); State v. Leon, 132 P.3d 462, 467 (Idaho Ct. App. 2008) (allowing musical accompaniment of video even though it was not a valid exercise of the victim's right to be heard); Salazar, 90 S.W.3d at 338 (finding the video was "“accompanied by irrelevant background music"”). 
while the State's interest in counteracting the defendant's mitigating evidence is protected.

\section{Relevance}

Evidence must be relevant to be admitted, but music is never relevant: it is always unnecessary and does not advance either of the two goals of VIS. Presenting background music with relevant pictures or videos does not make the music relevant. In fact, introducing evidence in a dramatic manner can even add irrelevant factors to otherwise relevant evidence. ${ }^{194}$ It is the actual testimony offered during VIS that describes the individual's uniqueness and informs those listening of the harm done. Even music that testimony shows is a favorite of the victim may not be relevant. ${ }^{195}$ In People v. Kelly, the victim's mother testified that the background music for the video was chosen because it was the victim's favorite. ${ }^{196}$ The court still found the music irrelevant, although not unduly prejudicial in that particular case. ${ }^{197}$ Courts conclude that background music is irrelevant time and time again, yet music is typically allowed when prosecutors introduce it along with relevant evidence.

The Court in Payne suggested that evidence presented during the sentencing phase should be considered in light of the trial as a whole. ${ }^{198}$ Although music should not initially be admitted, once it is admitted alongside relevant evidence, allowing prejudicial music is only a reversible error if it results in fundamentally unfair sentencing. To decide the fairness of the trial as a whole, courts will consider what other evidence the jury has seen. In Kelly, the court allowed an admittedly prejudicial videotape, explaining that "what this jury has heard from many other people makes this tape pale."199 In Petruccelli v. State, the court reasoned the state's strong evidence of appellant's guilt allowed the jury to view a highly emotional tape. ${ }^{200}$ This rationale, however, only works when an appellate court is considering the fairness of an entire

\footnotetext{
194. See People v. Kelly, 171 P.3d 548, 571-72 (Cal. 2007) (finding that presenting a video in dramatic manner adds irrelevant factors), cert. denied, 129 S.Ct. 564 (2008).

195. Id. at 571 .

196. Id.

197. Id. at 572 .

198. See Payne v. Tennessee, 501 U.S. 808, 823 (1991).

199. Kelly, 171 P.3d at 568 .

200. 184 S.W.3d 747, 749 (Tex. Crim. App. 2006).
} 
trial; it arguably does not fit within a trial court's initial application of Payne's limits on music.

Payne held that evidence can only be admitted if it meets either purpose of VIS. ${ }^{201}$ A court cannot allow for leniency depending on the amount of evidence proving the defendant's guilt. It is up to the trial court's broad discretion to decide whether to exclude evidence, yet it cannot be fair to allow emotional evidence in a strong case against a defendant when the same evidence would not be allowed in a weaker case. In cases with less incriminating evidence, the VIS could be the deciding factor between life and death, and, as the dissent in Payne cautioned, prejudicial use of evidence in these cases is even more troubling. ${ }^{202}$

In reaching our decision today, however, we should not be concerned with the cases in which victim impact evidence will not make a difference. We should be concerned instead with the cases in which it will make a difference. In those cases, defendants will be sentenced arbitrarily to death on the basis of evidence that would not otherwise be admissible because it is irrelevant to the defendants' moral culpability. The Constitution's proscription against the arbitrary imposition of the death penalty must necessarily proscribe the admission of evidence that serves no purpose other than to result in such arbitrary sentences. ${ }^{203}$

This discrepancy goes to the very heart of why courts need to consistently apply the Payne standard to prejudicial evidence and should no longer allow music during VIS. Merely because courts can retroactively find the trial to be fundamentally fair does not mean music is not prejudicial. Irrelevant and prejudicial music should not be admissible in the first place. Without its admission, an analysis of the entire trial would not even be required.

\section{Balancing Interests}

Upon applying a common balancing test to weigh the interests of the prosecution and defendant, it is apparent that admission of music during VIS is unnecessary and unwarranted. The Federal Rules of Evidence Rule 403's balancing test provides that "evidence may be excluded if its probative value is substantially outweighed by the danger of unfair

201. Payne, 501 U.S. at 827.

202. See Sullivan, supra note 41 , at 630.

203. Payne, 501 U.S. at 866 (Stevens, J., dissenting). 
prejudice." 204 Because this is similar to the standard in Payne, a comparable test to balance interests may be appropriate when deciding the admissibility of VIS. ${ }^{205}$ Music has no probative value: it provides no relevant information regarding the victim's uniqueness or the harm caused that cannot be expressed through spoken testimony. The danger of unfair prejudice, however, is high. ${ }^{206}$ Further, prohibiting the prosecution from presenting music during VIS places no burden on the government or the testifying victim. Barring background music does not deprive the testimony of any substance and the rule is easy to enforce, as it merely requires pressing the mute button. ${ }^{207}$

\section{Reason for Creation}

Other courts have looked to the reason why the tape was preparedwhether specifically for trial or for a memorial service. Videos and music prepared initially for a tribute to the victim are predictably more sentimental than those put together for evidentiary purposes, and the prejudice of such evidence will outweigh any probative value. As the Texas Court of Criminal Appeals declared in Salazar v. State, "the punishment phase of a criminal trial is not a memorial service for the victim. What may be entirely appropriate eulogies to celebrate the life and accomplishments of a unique individual are not necessarily admissible in a criminal trial." ${ }^{208}$ Tapes prepared for memorial services typically include background music; tapes prepared specifically for

204. FED. R. EVID. 403.

205. See Mathews v. Eldridge, 424 U.S. 319, 335 (1976) (balancing private interest and value of safeguards against governmental interest plus the burden of the procedural safeguards); see also Mark Stevens, Victim Impact Statements Considered in Sentencing: Constitutional Concerns, 2 CAL. CRIM. L. REV. 3 $₫ 48$ (2000).

206. See Kelly v. California, 129 S. Ct. 564, 567 n.3 (2008) (“I cannot help but wonder if Payne... would have been decided the same way if the Supreme Court Justices in the majority had ever sat as trial judges in a federal death penalty case and had observed first hand, rather than through review of a cold record, the unsurpassed emotional power of victim impact testimony on a jury. It has now been over four months since I heard this testimony [in a codefendant's case] and the juror's sobbing during the victim impact testimony still rings in the ears. This is true even though the federal prosecutors in [the case] used admirable restraint in terms of the scope, amount, and length of victim impact testimony." (quoting United States v. Johnson, 362 F. Supp. 2d 1043, 1107 (N.D. Iowa 2005)))

207. See People v. Zamudio, 181 P.3d 105, 136 (Cal. 2008) ("[T]he trial court excluded the videotape's audio portion-including music-finding it to be unduly prejudicial and inappropriate.”), cert. denied, 129 S. Ct. 567 (2008).

208. Salazar v. State, 90 S.W.3d 330, 335-36 (Tex. Crim. App. 2002). See also United States v. Sampson, 335 F. Supp. 2d 166, 192 n.12 (D. Mass. 2004) ("[T] the tape was made as a memorial tribute to [the victim] rather than produced for the purpose of this case. It was fitting and lovely for its original, intended purpose, but not appropriate for presentation to the jury . . .."). 
evidentiary purposes will most likely not. If music cannot be added for effect in other evidentiary exhibits, then a tape made for a memorial should not justify music's inclusion-especially when it would be simple to mute the sound.

\section{Ability to Supplement Other Testimony}

Courts have admitted emotional and even musical evidence as long as it supplements or adds to other testimony regarding the victim or the harm. The Court of Appeals of Maryland in Whittlesey v. State admitted a short video of the victim playing piano, a skill for which the victim was nationally known. ${ }^{209}$ In State v. Leon, the Idaho Court of Appeals admitted a video involving music that illustrated the victim at Christmas with her children. ${ }^{210}$ The court reasoned that admission of the tape was warranted because it illustrated prior testimony of the impact on the children, who were too young to present testimony to the court. ${ }^{211}$ Similarly, in People v. Prince, the California Supreme Court admitted a videotaped interview of the victim discussing her interests in singing and acting, which supplemented other testimony regarding her interests. ${ }^{212}$ The court did, however, exclude parts showing the victim actually performing, finding those portions to be cumulative. ${ }^{213}$ Even highly emotional evidence that supplements other testimony can be allowed as long as the probative value outweighs the potential prejudice. ${ }^{214}$ This rationale, however, still does not provide a valid reason for admitting music in VIS, as background music in picture montages does not add to or supplement the photos in any relevant way.

\section{CONCLUSION}

Advancing technology has opened the doors for prosecutors to bring in background music during VIS. Although the rules regarding admissibility vary throughout jurisdictions, courts must apply Payne's test to decide whether evidence in VIS is so unduly prejudicial that the result is fundamentally unfair. The majority of courts allowing VIS to include music have been wrongly applying Payne's test and

209. 665 A.2d 223, 230 (Md. 1995).

210. 132 P.3d 462, 467 (Idaho Ct. App. 2006).

211. Id.

212. 156 P.3d 1015, 1093-94 (Cal. 2007), cert. denied, 128 S. Ct. 887 (2008).

213. Id. at 1091-92.

214. See FED. R. Evid. 403. 
underestimating music's effect on emotion. At the very least, music has a prejudicial effect on emotion; other studies suggest that music even causes emotion. Studies done with mock-juries show that emotions affect decision-making. This means that using music during VIS is, by definition, undoubtedly prejudicial - it provides a tendency for jurors to make a decision based on something other than reason. ${ }^{215}$ The persuasive relationship between music and emotion establishes a high risk of prejudice and leaves no way to confirm whether a decision was reached through reason or emotion. This is enough to render the sentencing fundamentally unfair.

VIS are some of the most compelling evidence available to the prosecutor - they come directly from the hearts and mouths of survivors left behind. Because VIS are the most emotional parts of a sentencing, adding unnecessary and irrelevant music to VIS does nothing but add another prejudicial and emotional factor to the jurors' decision. By applying other factors that courts have considered relevant when deciding the admission of evidence, it is apparent that music should not be admitted. Background music does not have any probative value, as it does not provide any necessary or relevant information to the jury that is not gained through spoken testimony or pictures. As many courts readily admit, music is also irrelevant. Although courts have been unwilling to find the sentencing fundamentally unfair because of irrelevant music, this rationale does not follow Payne's test, which would not allow the music in the first place. After balancing the possible prejudice and probative value of music, it is evident that the lack of any probative value is outweighed by the grave danger of prejudice. Background music in evidence that was not created for evidentiary purposes does not need to be included and it is easy to take out. Finally, even if in some cases music may supplement or add to other relevant testimony, the background music that is the subject of this Comment does not. Allowing music during VIS causes prejudicial emotional decisions resulting in a fundamentally unfair sentencing and from this point on, courts must no longer allow music during VIS. 